\title{
O jogo irônico no romance $O$ casamento, de Nelson Rodrigues
}

\author{
Eugênio Drumond \\ PUC Minas
}

Eu direi tudo oportunamente. Neste ofício de romancista, ou se sabe de tudo da vida alheia, ou não se escreve nada.

Camilo Castelo Branco - A mulher fatal

\section{Um "jogo da verdade"}

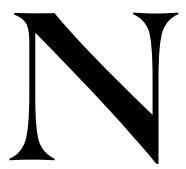

o romance O casamento, de 1966 - único que Nelson Rodrigues escreveu para ser publicado diretamente em livro e não em forma de folhetim - o narrador onisciente, que dá vOz às personagens, monta uma espécie de "jogo da verdade" em que elas, em todo o percurso da narrativa, ameaçam ou prometem "contar tudo" umas às outras, provocando no receptor do texto uma expectativa perene e uma grande curiosidade. Agindo assim, o narrador, irônico, finge que toda a história será esclarecida, visando jogar com a sagacidade/ ingenuidade do leitor que, guiado pela curiosidade, chegará até o final do romance mais desinformado que "esclarecido".

Apontar no texto elementos que demonstrem a insinuação que o narrador faz de "contar tudo" por meio de suas personagens, ou seja, localizar no romance enunciados que caracterizem o seu falso "jogo da verdade", não é tarefa das mais difíceis. No capítulo sete, por exemplo, narra-se que Noêmia, a secretária do protagonista, se prepara para um encontro amoroso com o patrão. Na ocasião, promete "contar tudo" à sua colega Sandra: "Depois te conto tudinho. Não digo agora pra não dar peso". ${ }^{1}$ Nesse caso, como em vários outros no decorrer da narrativa, o "contar tudo" não

${ }^{1}$ RODRIGUES, 1992, p. 5. 
corresponde em nada à "verdade dos fatos". Um outro exemplo se encontra na cena em que Camarinha fala a Glorinha sobre o beijo que Teófilo teria dado em Zé Honório: "(...) Vou te contar tudo. É melhor". ${ }^{2}$ Com referência também ao suposto beijo homossexual do noivo, narrase que Sabino já pensara que "há coisas que só um pai, ou só uma mãe, pode dizer. Sou pai, posso dizer tudo". ${ }^{3}$ As "confissões" seguem por aí afora: Zé Honório, falando de seu passado aos companheiros de orgia, diz que vai "contar tudo"; 4 Sabino, em conversa com o monsenhor, pergunta: "- Devo dizer tudo? - E repetia, fora de si: - Deve-se dizer tudo?", 5 ao que o religioso responde, enfaticamente: "- Meu filho, deve-se dizer tudo, exatamente tudo". ${ }^{6}$ Na seqüência, narra-se que "Sabino teve medo. 'Tudo', menos as fezes do pai". 7 É curioso como o "contar tudo" é enfatizado no diálogo que filha e pai travam no início do capítulo vinte e três:

- Ah, o senhor não me entende, papai! Não é isso. Nas nossas conversas, eu sinto, sabe? Sinto que o senhor não diz tudo. Nunca diz tudo.

- Mas tudo como? Digo sim, digo!

- Há coisas que o senhor não diz.

- Que coisas? Isso é muito vago. Que é que eu não digo?

- Ora, papai, ora!

Sabino está quase chorando:

- Glorinha, se eu digo tudo ou nem tudo, é o de menos.

Berrou:

- De menos, vírgula. A mim, o senhor devia dizer tudo! ${ }^{8}$

Na seqüência da cena acima, narra-se que "Glorinha aproxima o rosto: - Papai, posso dizer tudo?", 9 e insiste com Sabino: “- E o senhor também vai dizer tudo?", ao que a personagem responde: "- Tudo o quê? Digo, está bom. Digo tudo!"10

\footnotetext{
${ }^{2}$ RODRIGUES, 1992, p. 89.

${ }^{3}$ RODRIGUES, 1992, p. 39.

${ }^{4}$ RODRIGUES, 1992, p. 120.

5 RODRIGUES, 1992, p. 170.

${ }^{6}$ RODRIGUES, 1992, p. 171.

7 RODRIGUES, 1992, p. 171.

${ }^{8}$ RODRIGUES, 1992, p. 201.

9 RODRIGUES, 1992, p. 204.

${ }^{10}$ RODRIGUES, 1992, p. 204.
} 
Outro exemplo encontra-se na página 106, quando Maria Inês promete "explicar" a Glorinha coisas sobre o namorado, visto que ela não "sabia de tudo".

Esses exemplos demonstram que o autor, por meio de seu narrador onisciente, monta um jogo em que a expectativa é criada na voz das próprias personagens, supostamente dispostas a revelar às outras suas "verdades" mais recônditas. Contudo, a grande ironia que o narrador destina aos curiosos pode ser observada nos comentários que dirige a respeito da curiosidade de seus títeres. Por exemplo, no terceiro capítulo narra-se que "o ginecologista apanhou o retrato de Glorinha e o olhava com uma curiosidade grave". ${ }^{11}$ Na página quarenta e quatro, Glorinha diz a Camarinha, no consultório: "- Doutor, estou curiosíssima, morta de curiosidade. Mas acho que o senhor está fazendo suspense". Mais adiante, narra-se que Sabino "ouvia o caso da moça menstruada com uma curiosidade insaciável". ${ }^{12} \mathrm{O}$ mesmo sentimento tem Sandra, que, "doente de curiosidade", pergunta a Noêmia: “- Mandaste brasa?". ${ }^{13}$ Narra-se ainda, páginas adiante, que Camarinha, ao verificar que Glorinha já não é mais virgem, também é vitimado pelo desejo de saber: "Numa curiosidade, que o humilha, torna a perguntar: - Se não foi seu noivo, quem foi?". ${ }^{14}$

Assim, sempre lançando mão do discurso indireto, o narrador vai adjetivando a curiosidade como "mortal" 15 e "maligna", ${ }^{16}$ contrapondo-a à dissimulada "pré-disposição confessional" das personagens e instaurando um paradoxo: é a insinuação de se "contar tudo" que provoca a curiosidade das personagens ou é a bisbilhotice das mesmas que deflagra a "necessidade" de se "dizer tudo"? A grande ironia, no entanto, parece estar no fato de que agindo assim o autor esteja, no nível da enunciação, se dirigindo ao maior "curioso" em questão: o leitor de romances.

Em seu artigo "Artimanhas da ironia", Lélia Parreira Duarte ${ }^{17}$ escreve que a referência ao receptor é sinal de ironia num texto, pois evidencia

\footnotetext{
${ }^{11}$ RODRIGUES, 1992, p. 21.

${ }^{12}$ RODRIGUES, 1992, p. 51.

${ }^{13}$ RODRIGUES, 1992, p. 73.

${ }^{14}$ RODRIGUES, 1992, p. 88.

${ }^{15}$ RODRIGUES, 1992, p. 147.

${ }^{16}$ RODRIGUES, 1992, p. 176.

${ }^{17}$ DUARTE, 1991, p. 711.
} 
que a história que está sendo lida não tem voz própria e existe apenas quando há um leitor disposto a recebê-la do emissor, o qual, por sua vez, se autodenuncia comunicando-se ou não com o receptor por meio de sinais gráficos. Esses "avisos" irônicos parecem indicar que, apesar do esforço do escritor em deixar que seu texto dê a impressão de que a história seja real, nada do que se lê é verdade, pois aquelas personagens são apenas seres de papel e tinta. No fim das contas, o narrador se apresenta como articulador de uma história construída diante delas. Observa-se, nesse sentido, que o narrador de O casamento apenas finge distância, permanecendo sempre presente e próximo da mesma, por meio dos dêiticos e comentários dirigidos ao receptor, que funcionam como piscadelas a exibir ao leitor um escritor em ação. Assim, um leitor atento poderá perceber que esse narrador, desmentindo suas criaturas, arrancando-lhes as máscaras e desconstruindo suas convicções morais, amplia o foco de suas críticas, que podem passar do ambiente burguês carioca da década de sessenta do século passado para o do ser humano de modo geral, além de instaurar a conversa direta entre escritor e leitor de que nos fala Augusto Abelaira em artigo denominado "O jogo romanesco". Nesse texto, Abelaira escreve que os homens ocupam grande parte do seu tempo conversando e contando histórias que possam surpreender os amigos, e que um dos prazeres de contar consiste em ver o outro intervir, interrogar, enfim, jogar. Para ele, o romance não é mais que uma conversa de alguém (o escritor) que gosta de jogar com os outros (os leitores) e que

(...) na ausência deles imagina as mais diversas reações, prevê os comentários, os agrados e desagrados, procura pregar-lhes partidas e fica à espera - para depois, digerida a surpresa, talvez contra-atacada, pôr na mesa uma carta decisiva ou que pretende sê-lo. ${ }^{18}$

Em resumo, é assim que parece jogar o narrador de O casamento: por meio de múltiplas informações desencontradas e contraditórias, propõe que o leitor entre num jogo em que ele é quem dá as cartas, do alto de seus poderes demiúrgicos. Age como se viesse a desvendar toda a "verdade" de suas personagens a qualquer momento, mas freqüentemente sai de cena (sem nada esclarecer e depois de muito confundir o leitor) e deixa que essas, em discurso direto, se encarreguem de "dizer tudo", enquanto dizem, na verdade, quase nada. Concomitantemente, seus comentários aqui

${ }^{18}$ ABELAIRA, 1981, p. 32. 
e ali ironizam, como vimos, a curiosidade humana, no geral e, em particular, a curiosidade do leitor. Aliás, é a presença deste - reivindicada a todo custo pela voz narrativa - que torna vivo o romance de Nelson Rodrigues.

\section{Mudanças de registro e outras marcas de ironia}

O narrador onisciente de O casamento faz-se presente em todo o texto - apesar de simular objetividade, escondendo-se na "terceira pessoa" - e se intromete arbitrariamente na narrativa, principalmente por meio do uso de parêntese ou da presença dos dêiticos, como nesse exemplo: "graças a Deus, Sabino não estava, que sorte. Eudóxia apanhou não sei o que debaixo de um móvel". ${ }^{19}$ Note-se que esse "não sei o que" denuncia a presença do narrador e desmente, ironicamente, sua suposta onisciência. Uma outra maneira de o sujeito da enunciação fazer-se notar no texto é por meio da mudança brusca de registro, que é uma das vias para se alcançar ironia. Muitos dos exemplos já citados até aqui constituem mudanças de registro. É o que acontece, por exemplo, na frase "todo canalha é magro" - que se lê já na primeira página do livro - em que se mistura um quesito moral e um físico, caracterizando uma incompatibilidade que esvazia a seriedade do enunciado.

Em O casamento encontram-se, com freqüência, enunciados em que se vêem, lado a lado, elementos incompatíveis. Como os que se notam, por exemplo, no capítulo vinte, em que Sabino retorna à igreja e se "confessa" ao monsenhor que, por sua vez, retribui a "gentileza", confessando-se também. Não bastasse a incongruência da situação (o padre confessar-se com o fiel, o que, por si só, provoca um efeito cômico), em determinando momento narra-se que

Sabino pensa: "Minha filha vai se casar amanhã e eu não almocei". Diz para si mesmo: "Vomitei o que não comi".

O automóvel encostou na frente do edifício. Salta:

- Vai para o estacionamento e me espera lá.

Ao entrar no elevador, mudou de opinião: "Monsenhor respeitou a menina". Um santo pode ter ventas de fauno e alma de menina.O padre era essa menina. ${ }^{20}$

\footnotetext{
${ }^{19}$ RODRIGUES, 1992, p. 145.

${ }^{20}$ RODRIGUES, 1992, p. 177.
} 
Note-se que o fato (gravíssimo, para a personagem) de a filha se casar no dia seguinte é ligado a um prosaico almoço. Mais adiante, ao pensar que "um santo pode ter ventas de fauno e alma de menina", o narrador/autor irônico dá voz à personagem, novamente coloca lado a lado elementos incompatíveis e mistura aspectos da compleição física com a atitude moral do padre. No mesmo exemplo, a referência às "ventas de fauno" do monsenhor também caracteriza mudança de registro - e, portanto, também denuncia ironia - visto que une características humanas e animalescas.

Citações que precisassem essa marca pessoal do autor englobariam todo o texto, pois a todo instante encontramos comentários que apontam as conotações de sua própria linguagem, repleta dessas incongruências e hipérboles. De todo modo, vale registrar como se narra que, depois da sessão orgíaca da qual participam Antônio Carlos e Glorinha, "cai entre os dois uma paz desesperadora"; ${ }^{21}$ ou como se comenta, no capítulo nove, a cena em que a amante de Xavier propõe que ele abandone a esposa doente: "Noêmia repetiu, com alegre crueldade (...)";22 ou ainda como, logo no início do romance, a cafetina, "(...) impressionada com Sabino, a sua palidez de santo, o seu olhar lindo como um martírio, disse, baixo, sem desfitá-lo: - Vem comigo, vem". ${ }^{23}$

De certo modo, é nessa linha de análise que se situa a monografia de Flora Süssekind, Frases e ofundo falso, ${ }^{24} \mathrm{em}$ que a autora observa que o objetivo maior das frases "estranhas" que se encontram nos textos rodrigueanos é denunciar o eterno equívoco da opinião pública.

Para Flora, ao fazer afirmações dubitáveis, Nelson recorre ao mesmo procedimento do entimema ou silogismo filosófico, em que se ausentam ou a conclusão ou uma das premissas. Por exemplo, quando se diz que uma mulher deu à luz porque tem leite, cria-se um silogismo do qual simplesmente se omite a premissa maior, ou seja, que toda mulher que deu à luz tem leite. ${ }^{25}$ Flora lembra que "o ponto de partida do silogismo retórico está sempre no pensamento popular, no que é publicamente aceito como certo".${ }^{26} \mathrm{O}$

\footnotetext{
${ }^{21}$ RODRIGUES, 1992, p. 132.

22 RODRIGUES, 1992, p. 77.

${ }^{23}$ RODRIGUES, 1992, p. 6.

${ }^{24}$ SÜSSEKIND, 1977.

${ }^{25}$ Exemplo dado por ABBAGNANO, 2000, p. 896-897.

${ }^{26}$ SÜSSEKIND, 1977, p. 32.
} 
ouvinte se encarrega, então, de "completar" a frase, tendo a ilusão de que ele mesmo a constrói.

Registra a autora, todavia, que em Nelson a função do entimema é outra. A partir de enunciados como "todo canalha é magro", que provocam estranhamento no leitor, o autor de Álbum de família, no entender de Flora, estaria proporcionando a possibilidade de enxergarmos como, geradas de modo semelhante, nossas regras de conduta e opiniões mais corriqueiras podem esconder "absurdos" iguais. ${ }^{27}$

Em O casamento o leitor encontra várias dessas frases de "fundo falso", além da primeira delas, "todo canalha é magro", enunciado que faz Sabino mergulhar em seu primeiro fluxo de consciência e conclui um absurdo, ao misturar duas palavras de campos semânticos distintos, uma de significação moral e outra referente à compleição física, como já se afirmou. Sua antítese seria algo como "todo homem de bem é gordo", enunciado evidentemente absurdo.

Vejamos outro exemplo, que se encontra no extremo oposto do livro, em que protagonista ouve uma outra frase, essa, decisiva no romance. Trata-se do conselho que o monsenhor Bernardo dá ao pai de Glorinha, quando da visita que faz na véspera do casamento. O religioso, depois de um "sermão" em que conclui que "todos nós somos leprosos", 28 sem exceção, diz a Sabino: “- Assuma a sua lepra!", ${ }^{29}$ frase reflexiva de grande impacto, visto que, declarando-se culpado pela morte de Noêmia, no desfecho, Sabino parece estar assumindo o pecado - a sua "lepra" - que é o desejo que sente pela própria filha, além de ter sido descoberto como o estuprador da sobrinha epiléptica. O "homem de bem" (idéia fixa da personagem que perpassa toda a narrativa), era, pois, um fracassado. A frase do monsenhor faz também ressaltar a importância ficcional da esposa (anônima) de Xavier, que também é assassinada pela personagem, com um "tiro no sorriso". ${ }^{30}$ A mulher, leprosa, seria a representação alegórica da lepra social, para além da lepra individual a que se refere o padre.

Outro ponto que merece destaque são algumas intromissões do autor na narrativa, como a que se dá na passagem em que se narra que

\footnotetext{
27 SÜSSEKIND, 1977, p. 32.

${ }^{28}$ RODRIGUES, 1992, p. 250.

${ }^{29}$ RODRIGUES, 1992, p. 251.

${ }^{30}$ RODRIGUES, 1992, p. 236.
} 
Sabino, no mictório de um botequim, sente uma "alegria desesperadora" e que revê, "em imagens às vezes superpostas, às vezes sucessivas, todo o seu passado. Ele menino, a morte do pai, o banho das irmãs pequeninas, sua noite de núpcias, o nascimento das filhas, a fraldinha de Glorinha". ${ }^{31}$

É interessante observar nesse trecho que, por intermédio de seu narrador, o autor indica ao leitor como escreve o romance, pois a sucessão e a superposição dos flashbacks são a base da estrutura de O casamento, determinando o ritmo narrativo do romance e permitindo que as cenas do passado das personagens "expliquem" o universo diegético. Assim, descrevendo o fluxo de consciência de Sabino como uma revisão de "todo o seu passado", o narrador/autor dá uma de suas piscadelas e se comunica com o leitor atento, indicando como é que ele está narrando a sua história. Observe-se que esse procedimento possibilita ao leitor que ele se torne uma espécie de "cúmplice" do narrador, percebendo o exercício de linguagem constitutivo da leitura. Dessa forma, O casamento revela a imprescindibilidade de seu processo de enunciação, no qual se desvela a construção textual. Se por meio dos dêiticos e dos comentários a comunicação do narrador com o receptor já era patente, enunciados metalingüísticos como o do exemplo acima ressaltam ainda mais essa irônica exibição que faz o autor do ato de escrever. Outro exemplo de como isso se dá encontramos no capítulo vinte, num diálogo entre o monsenhor Bernardo e Sabino:

- Como você fez a sua confissão, eu tive idéia de fazer a minha.

Que tal? O confessor também se confessar? Está espantado?

- Oh, não e pelo contrário!

O padre riu:

- Que é o contrário do espanto? Mas vamos falar sério. ${ }^{32}$

Enunciado inteiramente deslocado do contexto, a pergunta da personagem "Que é o contrário do espanto?" parece denunciar um exercício metalingüístico. É como se o escritor, tendo usado uma expressão inadequada anteriormente na voz da personagem Sabino ("- Oh, não e pelo contrário!"), dialogasse consigo mesmo usando para isso a outra personagem (o monsenhor), ao invés de simplesmente retirar a frase da

\footnotetext{
${ }^{31}$ RODRIGUES, 1992, p. 54.

32 RODRIGUES, 1992, p. 174.
} 
"conversa", o que significava, naqueles tempos da datilografia, rasurar o texto. E, como refletir sobre a palavra "espanto" seria uma digressão desnecessária, o narrador simplesmente "muda de assunto", dando a fala ao monsenhor ("- Mas vamos falar sério"), como se dissesse: "vamos continuar a escrever o nosso romance".

Há ainda uma outra passagem que não deve ser esquecida. No último capítulo do romance, após a cena em que Sabino sucumbe à chantagem das três filhas e entrega um cheque de quatro milhões a cada uma delas, narra-se que a personagem, ao ouvir o chamado da esposa, que avisava sobre a chegada do monsenhor a casa,

(...) experimentava uma alegria desesperada. Eudóxia ou o monsenhor era a vida real. Ao passo que a chantagem das filhas era tão absurda, tão fantástica. E o defloramento, e a praia, e Glorinha descalça - tudo parecia tão irreal. ${ }^{33}$

Jogando com a hipótese de subdividir a matéria diegética num plano "real" e noutro "irreal", o narrador atinge um elevado nível de fingimento que proporciona, nesse caso, um grande realismo às personagens, além de sugerir que aqueles acontecimentos da véspera do casamento compõem o delírio de um pai enciumado. É como se, novamente fingindo ser verdade o que é pura invenção, o narrador irônico convidasse o receptor de seu texto a desvendar as armadilhas que montou, construindo com ele os sentidos do romance.

No caminho inverso, percebe-se uma outra marca de ironia em $O$ casamento quando o autor, repetindo cenas de outros textos seus, explicita que o que está fazendo é "apenas" literatura e, por instantes, deixa de fingir que o que está sendo narrado seja "real". Nesse caso, somente o leitor que conheça o restante da obra de Nelson - teatro, crônicas, contos e folhetins - perceberá que Teófilo é uma reedição do Edgar que, em Bonitinha, mas ordinária, também rasga um cheque-suborno e se liberta do jugo do poder econômico daquele que viria a ser o seu sogro. Da mesma forma, se esse leitor desconfiar que o narrador sugere a homossexualidade de Sabino, lembrar-se-á do desfecho da peça O beijo no asfalto, na qual, segundos antes de assassinar o genro, o sogro confessa seu amor por ele.

Por sua vez, o leitor habitual das crônicas do autor perceberá sua presença nas falas sobre futebol (opiniões sobre João Havelange, CBD e

${ }^{33}$ RODRIGUES, 1992, p. 247. 
o jogador Amarildo), arte (Drummond, Bilac e Salvador Dalí) e até mesmo na má-vontade que ele tinha com o paisagista Burle Marx. Note-se, finalmente, que essas intromissões do autor denunciam como ele manipula seus materiais e com eles joga com seu leitor.

\section{Referências Bibliográficas}

ABBAGNANO, Nicola. Dicionário de filosofia. Trad. Alfredo Bosi e Ivone Castilho Benedetti. São Paulo: Martins Fontes, 2000.

ABELAIRA, Augusto. O jogo romanesco. J L. Jornal de Letras, Artes e Idéias, Lisboa, n. 8, p. 32, jun. 1981.

DUARTE, Lélia Parreira. O riso. In: Românica, número 11, Lisboa, Colibri, 2002.

DUARTE, Lélia Parreira (Intr. e org.). Artimanhas da ironia. Boletim do Centro de Estudos Portugueses da FALE/UFMG, v. 11, n. 13, Belo Horizonte, p. 7-11, Jun. 1991.

ECO, Umberto. Lector in fabula. 2. edição. Trad. Attílio Cancian. Rio de Janeiro: Perspectiva, 2002, p. 35-46.

RODRIGUES, Nelson. O casamento. São Paulo: Companhia das Letras, 1992.

Teatro Completo: volume único. Organização geral, inclusive fortuna crítica, e prefácio de Sábato Magaldi. Rio de Janeiro: Nova Aguilar, 1993.

SÜSSEKIND, Flora. Frases e seu fundo falso. In: I Concurso Nacional de Monografias - 1976. 3‥ Lugar e prêmio de publicação. Brasília: MEC/Funarte/SNT, 1976.

\section{Resumo}

O texto estuda o romance O casamento, único escrito por Nelson Rodrigues para ser publicado diretamente em livro e não em capítulos diários de jornal. O enfoque é sobre a construção irônica do texto rodrigueano, responsável pela comicidade e humor presentes no livro.

\section{Abstract}

The text studies the novel O casamento, the only one written by Nelson Rodrigues to be published directly in book form and not serialized in daily chapters in a newspaper. The focus is on the ironic construction of Rodrigues' texts, responsible for the comicality and humor present in the book. 